Available online at www.jmle.org

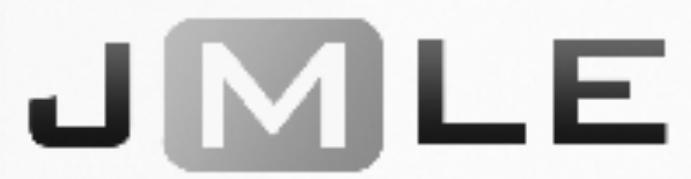

The National Association for Media Literacy Education's Journal of Media Literacy Education 10 (3), 171 - 174

\title{
BOOK REVIEW \\ Teaching Climate Change to Adolescents: Reading, Writing, and Making a Difference
}

\author{
Reviewed by \\ Antonio Lopez \\ John Cabot University, Italy
}

Teaching Climate Change to Adolescents: Reading, Writing, and Making a Difference by Richard Beach, Jeff Share and Allen Webb.

New York: Routledge, 2017

During 2012-13 I performed intensive research on North American media literacy education (MLE) practices to investigate why there were so few examples of environmentally-oriented perspectives in media literacy education (López, 2014). With the exception of the excellent work of Project Look Sharp (see Sperry, 2011), one is hard-pressed to find keywords like environment, ecology or climate change in media literacy lessons or organizational websites. As a result of the research (which included interviews with key practitioners), it became clear that the problem is not a of lack of interest or care, but the combination of a legacy in academia that siloes environmental studies from media studies, and a lack of training, knowledge and experience on the part of media literacy educators to teach subject matter outside of their expertise.

According to interviews, other barriers to integrating media literacy with environmental issues include: too many external pressures (time, standards, testing, funding, etc.); formal media literacy is mostly practiced in English language arts (ELA), which is not the standard place where environmental issues are taught; sustainability education is "persuasion," which does not pass the media literacy "smell test"; media literacy is "sealed off from the rest of life"; normative ethics can be a barrier to standards integration; "wigitization" of education policy is making it toolfocused; an attitude of NIMBYism (not in my backyard) leads people to believe the topic can and should be dealt with elsewhere; and a perception that environmental 
issues are associated with an "anti-progress" ideology, thereby making issues like climate change inherently anti-business and politically toxic.

Given this range of anxieties, it is not surprising that many media literacy educators are deciding to avoid environmental issues altogether. Bottom line: Who has time or the expertise to bridge the gap between the environment, climate change and media when there are so few opportunities or resources available to help teachers?

This is where Teaching Climate Change to Adolescents: Reading, Writing, and Making a Difference fits in. A timely book, it is a key resource that addresses the needs of those media literacy educators concerned with climate change. It can serve as a bridge until more intensive training is offered as professional development or in teacher colleges. Meanwhile, for the self-motivated this book is a practical and clearly written resource for ELA or MLE teachers with little or no scientific knowledge about climate change. As the title suggests, it is primarily targeting middle and high school ELA classrooms; however, anyone working with grade school or early year undergraduates can benefit from the book as well.

Though the book's title does not scream media literacy, many media literacy educators are probably aware of co-author Jeff Share's (2009) past work in critical media literacy, which has been honed at UCLA where he works in teacher education. The co-authors, Richard Beach and Allen Webb, are additionally situated in the world of teacher education, so their combined expertise offers a solid pedigree for the daily needs of classroom teachers.

Those steeped in the field will recognize the strategic relationship between ELA and MLE instruction, especially when aligning skills with Common Core State Standards. What might not be obvious is how science connects. The simple answer is that science alone is not going to solve the climate crisis, thus interdisciplinarity is critical, so the book itself, though focused on ELA instruction, bridges many disciplines by offering insights helpful to media literacy practitioners on how to blend teaching contemporary media examples (popular cinema, journalism, music or television) with the emerging genre of cli-fi (climate fiction) and science. Additionally, there is a chapter dedicated to critical media/digital analysis, which MLE practitioners can connect more directly with their own work. A section on writing can model potential projects for media production and there is an additional chapter dedicated to drama and gaming.

Chapter One starts with the assumption that most English teachers have little background in climate science, so it offers a clear explanation of the technical aspects of climate change. It also touches on the political and economic dimension of what drives climate change (i.e. agriculture, energy, water, consumerism, to name a few), to give a general overview of the problem from a cultural, political and societal perspective, especially as it relates to literature, media and journalism. Given the focus on ELA, the primary task is to relate climate change to narrative.

From that perspective, a central insight is that climate change is a story, and that "it has long been known that those who tell the stories, control the future" (p.1). Riffing on Paulo Freire, they argue that student learning is also about critically reading the world. As such, "In every discourse whether that be of science, the mass media, or literary, or cultural artifacts, climate change is a story, and the plot, the characters, and 
how that story has different variations. How that story is told makes a difference in how we understand it and respond to it" (p. 10). This includes studying a range of texts, such as climate representations in literature, nonfiction and media texts.

Aside from an introductory overview of climate science, the book's most practical resources are the various case studies, anecdotes and lesson plans from practitioners in the field that interweave throughout the text, including a whole chapter devoted to building climate change curricula. The authors' extensive experience in teacher training has enabled them to gather numerous innovative classroom projects and examples that educators can draw from. These case studies pull from diverse classroom settings with different student populations, so there are plenty of approaches to be inspired by.

A chapter on interdisciplinarity also demonstrates the various different ways teachers across disciplines can collaborate and work together (such as science, math, psychology, geography, history, social studies, and fine arts). This could also encourage media literacy educators to reach beyond their own boundaries. Significantly, the book has a comprehensive wiki of resources and teaching materials available at http://climatechangeela.pbworks.com/.

The book's one gap is that it is primarily focused on narrative. An ecomedia approach - which recognizes the material character of media and their impact on the environment-would complete the work (see Rust, Monani, \& Cubitt, 2016). For example, there could be an extended discussion on the connection between media consumption and $\mathrm{CO} 2$ emissions as a result of data clouds being primarily powered by coal. Or an exploration of the horribly toxic effect of screen gadgets and devices on regional ecosystems. Finally, there could be an exploration of the relationship between media technology and the tragedy of wars caused by the mining of rare earth minerals for our phones and tablets. All of these are important dimensions of climate change that can be taken into consideration whenever exploring media literacy and the environment.

The concern that sustainability education (and hence teaching about climate change) doesn't pass the media literacy "smell test" is the worry that environmentally concerned teachers are teaching persuasion rather than inquiry-based approaches. In the case of this book, the authors propose a critical inquiry method based on best practices in the classroom. What distinguishes their approach from more conventional MLE is that they are grounded in a very clear moral and ethical framework. Quite frankly, in my view such an ethical stance is severely lacking in common media literacy practices, which to my mind is in danger of drifting too far from its critical roots.

A strong example of how to move forward can be found in the authors' statement of values, which could inspire like-minded statements of principles that other media literacy organizations could craft for their websites. They write: "Our approach emerges from an understanding of the Anthropocene era in which we now live, when environmental, geological, and ecological systems are profoundly altered by human activity. Our beliefs are based on world citizenship, the rights and well-being of all, and the recognition of connections between the diverse members of the world family" ( $p$. 7). In practice this means foregrounding climate change as the "most important issue facing life on Earth"; gaining an understanding of "the causes and effects of climate 
change locally and globally, as well as the efforts to deny them"; adopting systemsbased, global perspectives to transition from individualism and nationalism; advocating for ecojustice through solidarity with those disproportionately affected by climate change; and "envisioning and enacting transformational change through individual and collective action, in which everyone is accountable for their actions and inactions" (pp. 7-8). So, like the field of environmental communication's challenge to media and communications studies, their starting point is that we are in the midst of a global environmental and climate emergency that behooves educators across disciplines to start incorporating the issue into their work, for in many senses, it is a master crisis that touches all aspects of life, including the future well-being of the students we are serving.

One of the conclusions that emerged from my research is that too often MLE remains stuck in the outdated legacy of $19^{\text {th }}$ century beliefs about individualism and progress. Given the point we are in our interconnected, global economy, it's time to update how we situate our teaching methods in a rapidly deteriorating planetary ecosystem. I worry that media literacy education - despite its good intentions - ends up being yet another way future vandals of the planet get trained (Orr, 1994), rather than preparing students to become green cultural citizens. My hope is that in coming years we will have more books like Climate Change in the English Classroom. Given the external pressures on teachers (lack of funding, more administrative tasks, etc.), educators are starving for resources like this that can explain in simple, jargon free language, steps, approaches, frameworks and background information that will help them integrate one of the most pressing and challenging issues of our time into their work.

\section{REFERENCES}

López, A. (2014). Greening media education: Bridging media literacy with green cultural citizenship. New York: Peter Lang.

Orr, D. W. (1994). Earth in mind: On education, environment, and the human prospect. Washington, DC: Island Press.

Rust, S., Monani, S., \& Cubitt, S. (2016). Ecomedia: Key issues. London; New York: Routledge.

Share, J. (2009). Media literacy is elementary: teaching youth to critically read and create media. New York: Peter Lang.

Sperry, S. (2011). Media constructions of sustainability: food, water and agriculture. Ithica: Project Look Sharp. 